\title{
PENGEMBANGAN MEDIA BERABASIS ADOBE FLASH PLAYER PENCEGAHAN, PERTOLONGAN, DAN PERAWATAN CEDERA OLAHRAGA BAGI GURU PENDIDIKAN JASMANI SEKOLAH MENENGAH PERTAMA (SMP)
}

\author{
Dede Irawan ${ }^{1 *}$, Sugiyanto ${ }^{2}$ \\ ${ }^{1}$ Ilmu Keolahragaan, Universitas Sebelas Maret \\ email : deirawan27@gmail.com
}

\begin{abstract}
Abstrak
Penelitian ini bertujuan menghasilkan produk berupa media pembelajaran interaktif berbasis adobe flash player. Konten dalam media ini berisikan materi pencegahan, pertolongan dan perawatan cedera olahraga bagi guru pendidikan jasmani SMP Negeri se-Kabupaten Pangandaran. Jenis penelitian ini merupakan penelitian dan pengembangan (Research and Development). Model pengembangan dalam penelitian ini diadaptasi dari model pengembangan Borg \& Gall. Berdasarkan tahapan-tahapan yang diadaptasi dari model pengembangan Borg and Gall maka didapatkan hasil penelitian sebagai berikut: Penilaian dan validasi ahli materi menunjukkan bahwa media pembelajaran sangat baik dengan nilai rerata 4,85. Penilaian dan validasi ahli media menunjukkan bahwa media pembelajaran sangat baik dengan nilai rerata 4,69 . Penilaian dan validasi dari ahli parktisi menunjukan media pembelajaran sangat baik dengan rerata 4,70. Hasil uji coba kelompok kecil menunjukkan hasil sangat baik yaitu rerata 4,50. Hasil uji coba kelompok besar menunjukkan hasil sangat baik dengan rerata 4,85. Pada uji operasional dan efektifitas produk, diberlakukan pre test dan post test terhadap 2 kelompok. Kelompok pertama yang diberikan pengaruh media, dan kelompok kedua sebagai kelompok kontrol. Uji operasional menunjukan penilain media dengan hasil sangat baik dengan rerata 4,89. Uji efektifitas menunjukan bahwa media pembelajaran interaktif memiliki keefektifan yang signifkan dengan nilai $t$ hitung $>t$ tabel yaitu $6,070>1,734$ dan nilai $\mathrm{p}$ (signifikansi) $0,000<0,05$ yang berarti bahwa media tersebut efektif. Sebagai simpulan akhir dinyatakan bahwa produk terbukti efektif meningkatkan pemahaman guru pendidikan jasmani di Kabupaten Pangandaran.

Kata kunci: Pendidikan Jasmani, Cedera, Media Pembelajaran Interaktif \& Pemahaman
\end{abstract}




\begin{abstract}
This research aims to produce interactive learning media based on adobe flash player. This media is containing the development of prevention, aid, and sport treatment injury for physical education teacher Junior High School throughout Pangandaran Regency. This study is research and development. The development model of this research is adapted from the development model of Borg \& Gall. Based on the stages adapted from the development model of Borg and Gall can be concluded as follows: the assessment and validation of the material expert provide that learning media is very good with average 4,85. The assessment and validation media expert provide that learning media is very good with average 4,69. The assessment and validation of the practitioner's expert provide that learning media is very good with average 4,70. The result test of small group shows very good result with average 4,50. The result of big group shows very good result on the average 4,85. On the operational test and effectiveness product are given pre test and post test toward two groups. The first group is given media effect and the second group as control group. The operational test shows media assessment with very good result that is 4,89 . The effectiveness test shows that interactive learning media is significant with $t$ count $>t$ table that is 6,070 > 1,734 and $p$ value (significance) 0,000 $<0,05$ which means that media is effective. In short, the product is effective to improve the physical education teacher's understanding in Pangandaran Regency.
\end{abstract}

Keywords: Physical education, Injury, Interactive Learning Media and

Understanding.

\title{
PENDAHULUAN
}

Pendidikan jasmani merupakan salah satu mata pelajaran di setiap jenjang sekolah, baik dari jenjang Sekolah Dasar (SD) atau sederajat sampai dengan Sekolah Menengah Atas (SMA) atau sederajat. Berbagai macam kegiatan yang harus dilakukan siswa di sekolah khusunya pada mata pelajaran pendidikan jasmani, tidak menutup kemungkinan terjadi suatu kecelakaan atau cedera dalam melakukan aktivitas jasmani tersebut. Secara umum siswa pernah mengalami cedera atau kecelakaan saat pembelajaran pendidikan jasmani yang berlangsung di sekolah. Hal ini membuat terganggunya proses pembelajaran baik bagi guru maupun siswa. Cedera olahraga yang terjadi sangat bermacammacam pada lokasi tubuh manusia, dari tingkat yang paling ringan yaitu berupa nyeri, keluhan lelah dan lesu berkepanjangan dan yang paling berat berupa hilangnya fungsi gerak karena cedera otot atau patah tulang, jika kondisi itu tidak ditangani dengan cepat, tentu dapat mengganggu aktivitas kehidupan dan kesehatan secara umum (Graha dan Priyonoadi, 2009). Selain cedera, kejadian seperti pingsan maupun kecelakaan dalam air ketika kegiatan olaharga rentan terjadi, seperti pembelajaran renang yang berpotensi terhadap kecelakaan tenggelam. Pembelajaran renang termasuk ke dalam silabus dan rencana pelaksanaan pembelajaran di sekolah. Sudah tentunya harus dilaksanakan di setiap sekolah.

Guru pendidikan jasmani meruapakan pemeran utama dalam memberikan suatu pembelajaran pendidikan jasmani di sekolah. Guru dituntut memiliki kualitas yang baik, dalam hal ini kemampuan guru akan mempengaruhi prestasi siswa. Kompetennya seorang guru dalam proses pendidikan sangat vital yaitu mengajar, disamping itu juga membimbing, mengarahkan dan menjadi fasilitator. Berkaitan erat dengan proses pembelajaran yang rentan terhadap terjadinya suatu cedera dan kecelakaan, 
diperlukan suatu kompetensi yang baik dari seorang guru terkait persiapan pelaksanan suatu pembelajaran pendidikan jasmani atau olahraga di sekolah, penanganan cedera dan kecelakaan yang baik dan benar oleh guru pendidikan jasmani. Bukan kewajiban pokok seorang guru harus memiliki kemampuan terhadap pertolongan dan perawatan cedera, karena di sekolah sudah terdapat UKS dan dokter sekolah. Tetapi mengingat di setiap sekolah belum tentu memiliki UKS yang berjalan dengan baik atau memiliki dokter di sekolah, terlebih dalam aktivitas jasmani atau olahraga di sekolah, guru pendidikan jasmani adalah orang yang paling dekat dengan siswa, maka apabila terjadi kecelakaan yang mengakibatkan cedera, guru pendidikan jasmani tersebut harus mempunyai kemampuan ekstra yaitu mampu menolong dan merawat siswanya yang mengalami cedera.

Berdasarkan hasil observasi awal di Kabupaten Pangandaran, guru pendidikan jasmani sekolah menengah pertama disana dapat dikaegorikan rendah pemahamannya terhadap pencegahan, pertolongan dan perawatan cedera olahraga. Oleh karena itu, didasari dengan permasalah tersebut, peneliti merasa perlu mengembangkan media untuk membantu meningkatkan kompetensi guru pendidikan jasmani terhadap pencegahan, pertolongan dan perawatan cedera olahraga. Peneliti memilih media berbasis adobe flash player sebagai media pembelajaran interaktif bagi guru pendidikan jasmani terkait pencegahan pertolongan dan perawatan cedera olahraga untuk meningkatkan kompetensi pemahaman guru pendidikan jasmani. Penggunaan media ini diharapkan mampu meningkatkan motivasi belajar guru, kompetensi guru dan dapat dijadikan sebagai sumber belajar yang mandiri guna mengatasi keterbatasan ruang dan waktu.

\section{METODE}

Jenis penelitian ini merupakan Research and Development. Model pengembangan dalam penelitian ini diadaptasi dari model pengembangan Borg \& Gall (1983). Adapun langkah-langkah penelitian pengembangan yang dilakukan Borg \& Gall yakni: (1) penelitian dan pengumpulan data (2) perencanaan, (3) pengembangan draf produk, (4) uji coba lapangan awal, (5) merevisi hasil uji coba, (6) uji coba lapangan, (7) penyempurnaan produk hasil uji lapangan, (8) uji pelaksanaan lapangan, (9) penyempurnaan produk akhir, (10) desiminasi dan implementasi.

\section{Tempat Penelitian}

Penelitian ini dilaksanakan di daerah Kabupaten Pangandaran, Jawa Barat. Kabupaten Pangandaran memiliki 10 kecamatan, yaitu: Kecamatan Parigi, Kecamatan Cijulang, Kecamatan Cimerak, Kecamatan Cigugur, Kecamatan Langkaplancar, Kecamatan Mangunjaya, Kecamatan Padaherang, Kecamatan Kalipucang, Kecamatan Pangandaran dan Kecamatan Sidamulih. Berdasarkan data yang diperoleh peneliti dari Kemendikbud di Kabupaten Pangandaran, Sekolah Menengah Pertama Negeri (SMP N) di kabupaten berjumlah 36 sekolah.

\section{Waktu Penelitian}

Waktu penelitian dilaksanakan pada bulan November sampai dengan sampai bulan Mei. Bulan November dan Desember dilaksanakan observasi awal, Januari dan Februari dilaksanakan pengembangan produk, Maret sampai Mei dilaksanakan uji coba kelompok kecil, kelompok besar dan uji operasional. 


\section{HASIL DAN PEMBAHASAN}

\section{Deskripsi Hasil Pengembangan}

Produk yang dihasilkan melalui penelitian pengembangan ini berupa media pembelajaran interaktif berbasis adobe flash player pencegahan, pertolongan dan perawatan cedera olahraga bagi guru pendidikan jasmani. Media berisi 4 macam materi dengan total pembahasan berjumlah 12 macam materi yaitu: (1) pencegahan cedera olahraga, (2) cedera luka yang didalamnya terdapat 10 macam cedera luka yaitu luka terbuka: luka lecet, luka iris, luka robek. Luka tertutup: luka memar, sprain dan strain, kram, dislokasi, fraktur dan penanganan pingsan, dan (3) kecelakaan dalam air. Produk ini dibuat menggunakan Adobe Flash CS6 Professional.

\section{Validasi Ahli Materi Media, Ahli Praktisi dan Uji Coba Produk}

Berdasarkan tahapan-tahapan yang diadaptasi dari model pengembangan Borg and Gall maka didapatkan hasil sebagai berikut: Penilaian dan validasi ahli materi menunjukkan bahwa media pembelajaran sangat baik dengan nilai rerata 4,85 . Penilaian dan validasi ahli media menunjukkan bahwa media pembelajaran sangat baik dengan nilai rerata 4, 69. Penilaian dan validasi dari ahli parktisi menunjukan media pembelajaran sangat baik dengan rerata 4,70. Hasil uji coba kelompok kecil menunjukkan hasil sangat baik yaitu rerata 4,50. Hasil uji coba kelompok besar menunjukkan hasil sangat baik dengan rerata 4,85 .

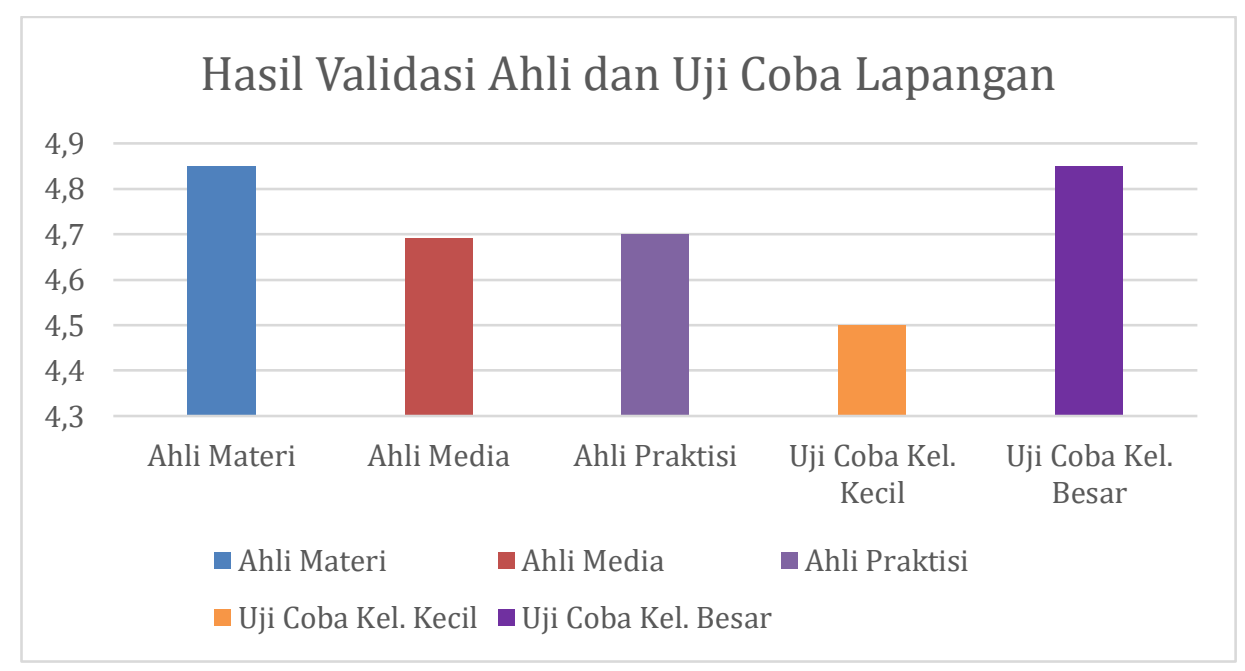

Gambar Diagram Hasil Validasi Ahli dan Uji Coba Lapangan

\section{Uji Operasional}

Berdasarkan hasil uji coba operasional dengan subjek 10 guru pendidikan jasmani di Kabupaten Pangandaran, terhadap tiga aspek penilaian yakni aspek tampilan, aspek isi atau materi, dan aspek pembelajaran dapat disimpulkan bahwa media termasuk kriteria "Sangat Baik" dengan rerata skor 4,89 . 


\section{Uji Efektifitas}

\section{Uji Normalitas}

Uji normalitas dilakukan untuk menguji apakah sampel berasal dari populasi yang terdistribusi normal atau tidak. Analis statistik untuk uji normalitas menggunakan uji Shapiro-Wilk yang dilakukan dengan program SPSS 21 Setelah dilakukan perhitungan uji normalitas dari data guru pendidikan jasmani adalah sebagai berikut:

Tabel 1. Data Uji Normalitas Shapiro-Wilk

\begin{tabular}{lcc}
\hline Data & Signifikansi $(p)$ & Kesimpulan \\
\hline Pre Test Makalah & 0,272 & Data berdistribusi normal \\
Post Test Makalah & 0,456 & Data berdistribusi normal \\
Pre Test Media & 0,974 & Data berdistribusi normal \\
Post Test Media & 0,060 & Data berdistribusi normal \\
\hline
\end{tabular}

Menurut Ali Maksum (2012), persyaratan data disebut normal pada uji Shapiro-Wilk jika taraf signifikansi atau probabilitas $p>0,05$. Data yang diperoleh dari hasil pre test, post test makalah dan media yang ditunjukkan pada tabel diatas, terlihat bahwa data diatas memiliki taraf signifikansi atau probabilitas $(p)$ lebih dari 0.05 ini artinya data pre test dan post test baik makalah atau pun media adalah berdistribusi normal.

\section{Uji Homogenitas}

Uji homogenitas bertujuan untuk mengetahui apakah sampel berasal dari varian yang sama atau tidak. Pada penelitian ini, uji homogenitas dilakukan dengan menggunakan Levene Test pada program SPSS 21. Hasil analisis data pre test dan post test makalah dan media dapat dilihat pada Tabel berikut:

Tabel Data Uji Homogenitas

\begin{tabular}{ccc}
\hline Data & Signifikansi & Ket \\
\hline pre test dan post test makalah dan media & 0,703 & Homogen \\
\hline
\end{tabular}

Dalam uji homogenitas berlaku ketentuan seperti uji normalitas, yakni: jika $p$-value lebih besar dibanding 0,05, maka data dinyatakan homogeny ( Maksum ,2012).

\section{Pengujian Hipotesis}

Pengujian hipotesis dilakukan mengenai ada tidaknya perbandingan yang signifikan antara "Media Pembelajaran Interaktif Pencegahan, Pertolongan dan Perawatan cedera olahraga" dan "Makalah Pencegahan, Pertolongan dan Perawatan Cedera Olahraga" yang dibagikan untuk kelompok kontrol. Berikut ini adalah data hasil Post test dan Pre Test Guru Pendidikan Jasmani: 
Tabel 38. Rata-rata hasil test dan nilai signifikansi p

\begin{tabular}{lcccc}
\hline Data & $\mathrm{N}$ & & Rata-rata & Sig p \\
\hline Makalah & 10 & Pre test & 14,1 & 0,005 \\
& & Post test & 18 & \\
Media & 10 & Pre test & 14,4 & 0,005 \\
& & Post test & 24,4 & \\
\hline
\end{tabular}

Berdasarkan data di atas terlihat bahwa hasil post test penggunaan media memiliki rerata lebih besar dengan nilai rerata 24,4 dibanding dengan penggunaan makalah dengan nilai rerata 18 . Untuk mengetahui perbandingan keefektivitasan antara "Media Pembelajaran Interaktif Pencegahan, Pertolongan dan Perawatan Cedera Olahraga" dan "Makalah Pencegahan, Pertolongan dan Perawatan Cedera Olahraga", kita tidak bisa langsung mengklaim bahwa rata-rata tersebut memiliki perbedaan yang signifikan. Oleh karena itu perlu dilakukan uji hipotesis (uji beda). Karena uji persyaratan yang telah dilakukan yaitu uji normalitas dan homogenitas telah terpenuhi maka pengujian hipotesis bisa dilakukan dengan menggunakan Independent Sample Test Untuk menghitung koefisien $t$ pada Independent Sample Test ini digunakan program SPSS 21.

Tabel Data Perbandingan Keefetivitasan Media Pembelajaran Interaktif dengan Makalah

\begin{tabular}{lccccc}
\hline \multirow{2}{*}{ Nilai } & \multicolumn{3}{c}{ Uji- $\boldsymbol{t}$} \\
\cline { 2 - 5 } & $\boldsymbol{t}$ & $\boldsymbol{d f}$ & Sig & $\boldsymbol{F}$ \\
\hline $\begin{array}{l}\text { Keefektifan } \\
\text { Interaktif dengan Makalah }\end{array}$ & 6,070 & 18 & 0,000 & 0,027 \\
\hline
\end{tabular}

Oleh karena nilai $\mathrm{t}$ hitung $>\mathrm{t}$ tabel $(6,070>1,734)$ dan $\mathrm{p}$ value $(0,000<0,05)$ maka Ho ditolak. Artinya bahwa ada perbedaan skor pegetahuan dan pemahaman tentang pencegahan, pertolongan dan perawtaan cedera olahraga pada kelompok guru yang diberikan media pembelajran interaktif dan guru yang diberikan makalah. Baik media maupun makalah yang diberikan kepada kelompok kontrol memiliki pengaruh dan efektifitas, namun pengaruh dan efektifitas media lebih baik daripada makalah. Maka media pembelajaran interaktif pencegahan, pertolongan dan perawatan cedera olahraga berpengaruh dan efektif untuk meningkatkan pemahaman guru pendidikan jasmani.

\section{KESIMPULAN}

1. Media pembelajaran interaktif pencegahan, pertolongan dan perawtaan cedera olahraga dikembangkan menggunakan pendekatan penelitian dan pengembangan $(\mathrm{R} \& \mathrm{D})$ dengan tahapan: (1) penelitian dan pengumpulan data (research and information collection), (2) perencanaan, (3) pengembangan draf produk, (4) uji coba lapangan awal, (5) merevisi hasil uji coba, (6) uji coba lapangan, (7) penyempurnaan produk hasil uji lapangan, (8) uji pelaksanaan lapangan, (9) penyempurnaan produk akhir, (10) desiminasi dan implementasi.

2. Produk akhir pengembangan materi ajar ini adalah media pembelajaran interaktif pencegahan, pertolongan dan perawatan cedera olahraga bagi guru pendidikan jasmani yang dikemas dalam CD 
untuk penyebar luasannya. Produk ini memuat materi tentang pencegahan cedera dengan pemanasan, pertolongan luka terbuka dan tertutup, pertolongan pingsan dan kecelakaan dalam air. Pengembangan media menggunakan software Adobe Flash CS6 Professional.

3. Berdasarkan validasi ahli, uji coba kelompok dan uji operasional maka media pembelajara interaktif ini dinyatakan valid. Ahli materi yang menilai dari aspek kualitas materi dan aspek isi dengan rerata 4,85 termasuk katergori sangat baik, sedangkan ahli media menilai dari aspek tampilan dan aspek pemrograman dengan rerata skor sebesar 4,69 termasuk kategori sangat baik. Penilaian ahli praktisi berdasarkan aspek tampilan, aspek isi, dan aspek pembelajaran diperoleh rerata skor sebesar 4,70 termasuk kategori sangat baik. Hasil uji coba kelompok kecil dan besar, berdasarkan aspek tampilan, aspek isi, dan aspek pembelajaran diperoleh rerata skor sebesar 4,50 dan 4,85 termasuk kategori sangat baik. Sedangkan hasil uji coba operasional nilai rerata 4,89 termasuk kategori sangat baik.

4. Produk hasil penelitian dan pengembangan materi ajar berupa media pembelajaran interaktif pencegahan, pertolongan dan perawatan cedera olahraga bagi guru pendidikan jasmani dinyatakan valid dan efektif.

\section{DAFTAR PUSTAKA}

Graha, Ali Satia dan Bambang Priyonoadi. 2009. Terapi Masase Frirage. Pelaksanaan cedera pada anggota tubuh bagian atas. Yogyakarta: FIK UNY.

Sudijandoko, Andun. 2000. Perawatan dan Pencegahan Cedera. Jakarta: Depdiknas

Sudijono, Anas. 2005. Pengantar Evaluasi Pendidikan. Jakarta: Raja Grafindo Persada

Sukadiyanto. 2010. Pengantar Teori dan Metodologi Melatih Fisik. Yogyakarta: UNY Press.

Suryobroto, Agus. 2001. Teknologi Pembelajaran Pendidikan Jasmani. Yogyakarta: FIK UNY.

TBMM. 2002. Buku Panduan Pelatihan Basic Life Support. Yogyakarta: Panacea

Thoha, M. Chabib. 1991. Teknik Evaluasi Pendidikan. Jakarta: Rajawali. 